\title{
Pengaruh Rasio Tepung Ampas Kelapa dan Singkong Parut Terhadap Sifat Kimia dan Sensoris Kue Klenyem
}

\section{The Effect of the Ratio of Coconut Pulp Flour and Grated Cassava On the Chemical and Sensory Properties of the Klenyem Cake}

\author{
Ika Septiana ${ }^{1}$, Luh Putu Trisna Darmayanti ${ }^{1 *}$, I Made Sugitha ${ }^{1}$ \\ Program Studi Teknologi Pangan, Fakultas Teknologi Pertanian, Universitas Udayana \\ Kampus Bukit Jimbaran, Badung-Bali \\ *Penulis korespondensi: LP Trisna Darmayanti, Email: trisnadarmayanti@unud.ac.id
}

\begin{abstract}
This research aims to determine the comparison effect of coconut pulp flour with grated cassava on the characteristics of klenyem cake, and to find out the exact ratio of coconut flour and grated cassava so as to produce the best characteristics of klenyem cake. The experimental design used Completely Randomized Design (CRD) with treatment of coconut pulp flour and grated cassava ratio consist 6 levels : $20 \%: 80 \%$; 30\%: 70\%; 40\%: 60; 50\%: 50\%; 60\%: 40\%; 70\%: 30\%. Each treatment was repeated 3 times so obtained 18 experimental units. The parameters observed were water content, ash content, protein content, fat content, carbohydrate content, crude fiber content and the sensory test of the klenyem cake. The data obtained were using Analysis of Variance (ANOVA) and if the significant effect to the variables, followed by The Duncan Multiple Range Test (DMRT). The results showed that the comparison of coconut pulp flour and grated cassava have a significant effect on the water content, ash content, protein content, fat content, carbohydrate content, crude fiber content, color and texture (scoring), aroma, taste and overall acceptance (hedonic). Comparison of coconut pulp flour with grated cassava $40 \%$ : $60 \%$ has been able to produce the best characteristics of klenyem cake. The parameter results of $40 \%$ coconut pulp flour with $60 \%$ grated cassava that is water content $32.54 \%$, ash content $1.78 \%$, protein content $2.85 \%$, fat content $33.72 \%$, carbohydrate content $33.61 \%$, crude fiber content $21.62 \%$, yellow color, soft texture, aroma liked, taste liked and overall acceptance liked.
\end{abstract}

Keywords : coconut pulp flour, grated cassava, klenyem cake

\section{PENDAHULUAN}

Indonesia memiliki beragam jenis produk pangan tradisional. Salah satunya merupakan produk makanan dari olahan singkong (Manihot utilissima L), seperti : keripik singkong, ceriping, kolak dan kue. Kue yang berbahan dasar dari singkong ada berbagai macam jenisnya, yaitu; kue gethuk lindri, kue klepon, kue sawut, kue talam, dan kue klenyem. Kue klenyem merupakan salah satu jenis produk jajanan tradisional
Indonesia khususnya di Provinsi Jawa Tengah. Kue klenyem termasuk jajanan tradisional yang sering ditemui di pasar tradisional. Kue klenyem juga mempunyai sebutan lain di berbagai daerah seperti ; Jemblem sebutan dari wilayah Jawa Timur, Misro (Sunda), Ondol - ondol (Pemalang), Sotho Galeng (Ngadirejo, Parakan), Blendung Watung (Pekalongan), Krandon (Jawa Tengah), Jotosan atau Klenyem (Jawa Tengah), dan Pulung Ubi (Bali) (Anon, 
2011).

Bahan baku dari kue klenyem secara umum adalah singkong parut dan kelapa parut. Kue klenyem dikenal memiliki kandungan karbohidrat yang tinggi dikarenakan bahan dari pembuatan kue klenyem banyak mengandung singkong. Karbohidrat memiliki beberapa kandungan senyawa - senyawa yang dibutuhkan untuk tubuh, salah satunya pektin. Adanya pektin yang berlebihan mengakibatkan tekstur yang keras pada produk. Keadaan tekstur dari kue klenyem yang terdapat di pasar tradisional masih keras atau kurang lembut saat digigit. Oleh karena itu, pada penelitian ini akan dilakukan penambahan tepung ampas kelapa sebagai pengganti dari kelapa parut. Penambahan tepung ampas kelapa diharapkan berguna untuk memperbaiki karakteristik dari kue klenyem. Diketahui tepung ampas kelapa banyak mengandung lemak yang tinggi dibandingkan singkong parut. Tepung ampas kelapa memiliki kandungan lemak berkisar 12,2\% (Yulvianti, et al. 2015), lebih tinggi dibandingkan dengan singkong varietas adira yang hanya 0,83\% ( Feliana, et al. 2014). Adanya kadar lemak yang tinggi berperan untuk memperbaiki tekstur dari kue klenyem agar menjadi lebih lembut.

Penambahan tepung ampas kelapa juga mempunyai nilai tambah untuk kue klenyem. Tepung ampas kelapa diketahui banyak mengandung kadar serat yang tinggi. Hal ini dibuktikan dalam penelitian
(Yulvianti, 2015) menyatakan bahwa tepung ampas kelapa memiliki kadar serat kasar $20 \mathrm{~g}$ per $100 \mathrm{~g}$ sampelnya, lebih tinggi dibandingkan dengan singkong yang hanya memiliki kadar serat kasar $0,73 \mathrm{~g}$ per $100 \mathrm{~g}$ sampelnya (Feliana, et al. 2014). Fungsi utama dari serat kasar yaitu dapat mengikat air. Serat kasar mengandung selulosa dan pektin. Selain itu, serat kasar juga membantu kinerja usus besar dalam mengeluarkan sisasisa makanan yang terdapat di dalam perut dalam bentuk feses.

Menurut (Trinidad, dkk (2006) dalam Rosnah dan Wa Zulhija (2018)) menyatakan keunggulan utama tepung ampas kelapa adalah kandungan serat pangan yang sangat tinggi. Tepung ampas kelapa mengandung $60,9 \mathrm{~g}$ total serat pangan dalam setiap 100 gram sampel, yaitu 56,8 g serat tidak larut dalam air (insoluble fiber) dan 3,8 g serat larut dalam air (soluble fiber) serta serat kasar (crude fiber) sebanyak 15 g. Jumlah ini secara signifikan lebih besar dibandingkan kandungan serat pangan pada sumbersumber serat lainnya seperti tepung pisang, kasava, gandum dan beras. Menurut penelitian (Yulvianti, et al. 2015) menyatakan bahwa tepung ampas kelapa memiliki kadar lemak $12,2 \%$, protein $18,2 \%$, serat kasar 20\%, abu 4,9\%, dan kadar air $6,2 \%$.

Menurut (Putri, 2014) tingkat kematangan buah kelapa yang digunakan untuk pembuatan tepung ampas kelapa berkisar umur dari 8 sampai 13 bulan. 
Sedangkan untuk tingkat kematangan dari umbi singkong yang digunakan dalam pembuatan kue klenyem berkisar umur 7 bulan setelah tanam atau 12 bulan setelah tanam tergantung varietas yang ditanam. Hal ini dibuktikan dalam penelitian (Feliana, et al. 2014) pada penelitian yang dianalisis secara umum yakni singkong varietas adira berumur 7 bulan dan singkong varietas bogor berumur 12 bulan. Apabila singkong dipanen melewati batas waktu yang telah ditentukan maka umbinya akan mengeras (berkayu) sehingga tidak baik lagi untuk dikonsumsi masyarakat.

Pemanfaatan penggunaan tepung ampas kelapa dalam pembuatan kue klenyem belum diketahui, dikarenakan belum ada penelitiannya. Oleh karena itu, dilakukan penelitian dengan tujuan untuk mengetahui pengaruh perbandingan tepung ampas kelapa dan singkong parut terhadap sifat kimia dan sensoris kue klenyem, dan untuk mengetahui pengaruh perbandingan tepung ampas kelapa dengan singkong parut yang dapat menghasilkan kue klenyem dengan karakteristik yang terbaik. Hasil dari penelitian tersebut diharapkan mampu untuk menambah keanekaragaman produk pangan.

\section{METODE PENELITIAN}

\section{Tempat dan Waktu}

Penelitian ini dilakukan di laboratorium Pengolahan Pangan dan Analisis Pangan, Fakultas Teknologi Pertanian, Gedung Agrokomplek
Universitas Udayana, Jalan Jendral Sudirman, Denpasar, Bali. Penelitian dilaksanakan bulan November 2019 sampai Januari 2020.

\section{Bahan dan Alat}

Adapun bahan - bahan yang digunakan dalam penelitian ini, antara lain: singkong parut, kelapa parut, gula merah, gula pasir, garam, dan minyak goreng bahan - bahan ini dapat diperoleh di pasar tradisional. Bahan kimia yang digunakan adalah $\mathrm{H}_{2} \mathrm{SO}_{4}, \quad \mathrm{NaOH}, \quad$ indikator phenolphatelin (PP), $\mathrm{HCl}$, tablet Kjeldahl, Alkohol 96\%, Larutan Asam Borat, NHeksan, dan Aquades.

Alat yang digunakan dalam penelitian ini adalah kompor gas, sendok penggorengan, parutan kayu, baskom, mangkok, piring, sendok makan, oven (Memmert), spatula, alat titrasi, pisau, talenan, wajan, blender (Miyako), ayakan 60 mesh, cawan porselen, timbangan analitik (Shimadzu), tabung reaksi (Pyrex), gelas beker (Pyrex), erlenmeyer (Pyrex), gelas ukur (Pyrex), Destilator, Muffle (Daihan), biuret (Pyrex), pompa bulb, labu kjedhal (Pyrex), labu lemak (Pyrex), soxhlet, pipet tetes, tissue, plastik HDPE, benang wol, kertas saring, kertas whatman no 42, waterbath, gelas beker (Pyrex), gelas ukur, seperangkat alat untuk evaluasi sensoris dan aluminium foil (Klin Park).

\section{Rancangan Percobaan}

Penelitian ini menggunakan metode eksperimental dengan Rancangan Acak 
Lengkap (RAL) dengan perlakuan perbandingan tepung ampas kelapa dengan singkong parut yang terdiri dari 6 taraf sebagai berikut : P1 = Tepung Ampas Kelapa $20 \%$ dan Singkong parut $80 \%$, P2 = Tepung Ampas Kelapa 30 \% dan Singkong parut $70 \%$, P3 = Tepung Ampas Kelapa 40 $\%$ dan Singkong parut $60 \%$, P4 = Tepung Ampas Kelapa $50 \%$ dan Singkong parut 50 $\%$, P5 $=$ Tepung Ampas Kelapa $60 \%$ dan Singkong parut $40 \%$, P6 = Tapung Ampas Kelapa $70 \%$ dan Singkong parut $30 \%$. Perlakuan ini diulang sebanyak tiga kali sehingga diperoleh 18 unit percobaan. Data hasil penelitian dengan analisis ragam dan bila terdapat pengaruh perlakuan terhadap parameter yang diamati maka dilanjutkan dengan uji Duncan.

\section{Pelaksanaan Penelitian}

Dalam pelaksanaan penelitian terdiri dari dua tahapan yaitu tahap pertama pembuatan tepung ampas kelapa dan tahap kedua pembuatan kue klenyem.

\section{Pembuatan Tepung Ampas Kelapa}

Tahap pertama yang harus disiapkan adalah kelapa parut yang diperoleh dari pasar tradisional. Kemudian kelapa parut diperas dihilangkan kandungan airnya sampai menjadi ampas kelapa. Ampas kelapa dikukus selama 3 menit. Ampas kelapa kemudian dioven selama \pm 5 jam dengan suhu $60^{\circ} \mathrm{C}$ atau sampai kering. Ampas kelapa kemudian dihaluskan menggunakan blender dan diayak dengan ayakan 60 mesh (Wardani, 2016 yang telah dimodifikasi)

\section{Pembuatan Kue Klenyem}

Mula - mula disiapkan singkong parut yang diperoleh dari pasar tradisional. Kemudian ditambahkan tepung ampas kelapa dengan perlakuan $(20 \%, 30 \%, 40 \%$, $50 \%, 60 \%, 70 \%$ ) lalu ditambahkan gula pasir $5 \mathrm{~g}$ dan garam $1 \mathrm{~g}$ pada setiap perlakuan, dicampur hingga homogen. Setelah homogen dilakukan pembentukan adonan bulat - bulat atau oval dengan diameter berkisar $\pm 5 \mathrm{~cm}$. Kemudian dimasukan gula merah $20 \mathrm{~g}$ ke dalam adonan. Tahap terakhir dilakukan penggorengan dengan metode deep fat frying dalam suhu $180^{\circ} \mathrm{C}$ selama 60 detik. Metode deep fat frying merupakan proses penggorengan di mana suatu bahan makanan yang umumnya mengandung air, diproses dalam minyak goreng panas dalam jumlah yang besar (Anon, 2015b yang telah dimodifikasi).

\section{Variabel yang diamati}

Variabel yang diamati yaitu kadar air dengan menggunakan metode gravimetri (Sudarmadji, et al. 1997), kadar abu ditentukan dengan metode gravimetri bahan basah (Sudarmadji, et al. 1997), kadar protein menggunakan metode mikroKjeldahl (Sudarmadji, et al. 1997), kadar lemak ditentukan dengan metode soxhlet (Sudarmadji, et al. 1997), kadar karbohidrat ditentukan dengan metode carbohydrate by different (Sudarmadji, et al. 1997), kadar serat kasar berdasarkan metode hidrolisis asam basa (Sudarmadji, et al. 1997), dan 
sifat sensoris diuji dengan menggunakan metode uji skoring warna dan tekstur dan uji hedonik aroma, rasa, dan penerimaan keseluruhan (Soekarto, 1985).

Tabel 1. Formula kue klenyem.

\begin{tabular}{lcccccc}
\hline \multirow{2}{*}{ Bahan } & \multicolumn{7}{c}{ Perlakuan } \\
\cline { 2 - 7 } & $\mathbf{P}_{\mathbf{1}}$ & $\mathbf{P}_{\mathbf{2}}$ & $\mathbf{P}_{\mathbf{3}}$ & $\mathbf{P}_{\mathbf{4}}$ & $\mathbf{P}_{\mathbf{5}}$ & $\mathbf{P}_{\mathbf{6}}$ \\
\hline Tepung Ampas Kelapa (\%) & 20 & 30 & 40 & 50 & 60 & 70 \\
Singkong parut (\%) & 80 & 70 & 60 & 50 & 40 & 30 \\
Gula merah (\%) & 20 & 20 & 20 & 20 & 20 & 20 \\
Gula pasir (\%) & 5 & 5 & 5 & 5 & 5 & 5 \\
Garam (\%) & 1 & 1 & 1 & 1 & 1 & 1 \\
\hline
\end{tabular}

Sumber: Anon, (2015b) ; telah dimodifikasi.

Keterangan: Presentase (\%) penambahan gula merah, gula pasir dan garam dihitung berdasarkan jumlah tepung ampas kelapa dan singkong parut yang digunakan pada setiap perlakuan.

\section{HASIL DAN PEMBAHASAN}

\section{Hasil Sifat Kimia Kue Klenyem}

Hasil sidik ragam menunjukkan bahwa perbandingan tepung ampas kelapa dengan singkong yang diparut berpengaruh sangat nyata $(\mathrm{P}<0,01)$ terhadap karakteristik kue klenyem. Nilai rata - rata kadar air, kadar abu, kadar protein, kadar lemak, kadar karbohidrat, dan kadar serat kasar dari kue klenyem dapat dilihat pada Tabel 2.

\section{Kadar Air}

Hasil sidik ragam menunjukkan bahwa perbandingan tepung ampas kelapa dengan singkong parut berpengaruh sangat nyata $(\mathrm{P}<0,01)$ terhadap kadar air kue klenyem. Tabel 2 menunjukkan kadar air kue klenyem berkisar antara $11,27 \%$ sampai dengan
41,27\%. Kadar air kue klenyem tertinggi diperoleh dari kue Klenyem pada perlakuan P1 (20\% tepung ampas kelapa dan 80\% singkong yang diparut) yaitu sebesar 41,27\%, sedangkan kadar air kue Klenyem terendah diperoleh pada perlakuan P6 (70\% tepung ampas kelapa dan 30\% singkong yang diparut) yaitu sebesar 11,27\%.

Kadar air kue klenyem juga mengalami penurunan seiring dengan penambahan tepung ampas kelapa. Hal ini disebabkan kadar air tepung ampas kelapa lebih rendah dibandingkan singkong. Hasil penelitian (Septiriyani, 2017) menyatakan bahwa umbi singkong memiliki kadar air sebesar $62,5 \%$ dan tepung ampas kelapa hanya memiliki kadar air 6,2\% (Yulvianti, et al. 2015). 
Tabel 2. Nilai rata - rata hasil sidik ragam sifat kimia kue klenyem.

\begin{tabular}{|c|c|c|c|c|c|c|}
\hline $\begin{array}{c}\text { Perlakuan } \\
\text { (Tepung } \\
\text { Ampas } \\
\text { Kelapa : } \\
\text { Singkong } \\
\text { Parut) }\end{array}$ & $\begin{array}{l}\text { Kadar } \\
\text { Air } \\
(\%)\end{array}$ & $\begin{array}{c}\text { Kadar } \\
\text { Abu (\%) }\end{array}$ & $\begin{array}{c}\text { Kadar } \\
\text { Protein }(\%)\end{array}$ & $\begin{array}{c}\text { Kadar } \\
\text { Lemak (\%) }\end{array}$ & $\begin{array}{c}\text { Kadar } \\
\text { Karbohidrat } \\
(\%)\end{array}$ & $\begin{array}{c}\text { Kadar Serat } \\
\text { Kasar (\%) }\end{array}$ \\
\hline P1 (20:80) & $\begin{array}{c}41,27 \\
\mathrm{a}\end{array}$ & $1,51 \mathrm{~cd}$ & $2,41 \mathrm{c}$ & $14,44 \mathrm{e}$ & $26,81 b$ & $14,91 \mathrm{e}$ \\
\hline P2 (30:70) & $\begin{array}{c}39,13 \\
b\end{array}$ & $2,73 \mathrm{a}$ & $2,64 \mathrm{c}$ & $15,37 \mathrm{e}$ & $24,09 \mathrm{bc}$ & $17,16 \mathrm{de}$ \\
\hline P3 (40:60) & $\begin{array}{c}32,54 \\
\mathrm{c}\end{array}$ & 1,78 bc & $2,85 \mathrm{bc}$ & $16,91 \mathrm{~d}$ & $33,61 \mathrm{a}$ & $21,62 \mathrm{~cd}$ \\
\hline P4 (50:50) & $\begin{array}{c}30,27 \\
\mathrm{~d}\end{array}$ & $2,73 \mathrm{a}$ & $3,52 \mathrm{ab}$ & $20,30 \mathrm{c}$ & $21,09 \mathrm{~cd}$ & $26,13 \mathrm{c}$ \\
\hline P5 (60:40) & $\begin{array}{c}22,65 \\
\mathrm{e}\end{array}$ & $2,20 \mathrm{ab}$ & $3,97 \mathrm{a}$ & $27,12 \mathrm{~b}$ & $18,58 \mathrm{~d}$ & $36,61 \mathrm{~b}$ \\
\hline P6 (70:30) & $11,27 \mathrm{f}$ & $1,15 \mathrm{~d}$ & $4,39 \mathrm{a}$ & $30,54 \mathrm{a}$ & $21,84 \mathrm{~cd}$ & $45,99 \mathrm{a}$ \\
\hline
\end{tabular}

\section{Kadar Abu}

Hasil sidik ragam menunjukkan bahwa perbandingan tepung ampas kelapa dengan singkong parut berpengaruh sangat nyata $(\mathrm{P}<0,01)$ terhadap kadar abu kue klenyem. Hasil pengujian kadar abu menunjukkan bahwa kue klenyem mengandung residu abu sebesar $1,15 \%$ sampai dengan $2,73 \%$.

Perbedaan nilai kadar abu kue klenyem yang mengalami non signifikan dari beberapa perlakuan. Disebabkan oleh nilai kadar abu pada tepung ampas kelapa lebih tinggi dibandingkan singkong parut. Hasil ini dibuktikan dalam penelitian (Yulvianti, et al., 2015) menyatakan bahwa kadar abu tepung ampas kelapa 4,9\%, sedangkan kadar abu singkong varietas adira mengandung 0,66\% (Feliana, et al., 2014).

\section{Kadar Protein}

Hasil sidik ragam menunjukkan bahwa perbandingan tepung ampas kelapa dengan singkong parut berpengaruh sangat nyata $(\mathrm{P}<0,01)$ terhadap kadar protein kue Klenyem. Pada Tabel 2 menunjukkan kadar protein kue klenyem berkisar antara 2,41\% sampai dengan 4,39\%. Kadar protein tertinggi diperoleh pada perlakuan P6 (70\% tepung ampas kelapa dan 30\% singkong parut) yaitu 4,39\%. Kadar protein terendah diperoleh pada perlakuan P1 (20\% tepung ampas kelapa dan $80 \%$ singkong parut) yaitu $2,41 \%$.

Kandungan protein kue klenyem mengalami peningkatan dengan semakin banyaknya penambahan tepung ampas kelapa. Semakin tinggi kosentrasi tepung ampas kelapa, maka kadar protein kue klenyem semakin tinggi. Hal ini disebabkan 
karena kadar protein pada tepung ampas kelapa lebih tinggi dibandingkan dengan singkong. Hal ini dibuktikan dalam penelitian (Yulvianti, et al. 2015) menyatakan bahwa tepung ampas kelapa mengandung protein sebesar 18,2\%, sedangkan kadar protein untuk singkong hanya sebesar 1,2\% (Septiriyani, 2017).

\section{Kadar Lemak}

Hasil sidik ragam menunjukkan bahwa perbandingan tepung ampas kelapa dengan singkong parut berpengaruh sangat nyata $(\mathrm{P}<0,01)$ terhadap kadar lemak kue klenyem. Tabel 2 menunjukkan kadar lemak kue klenyem berkisar antara 14,44\% sampai dengan 30,54\%. Kadar lemak kue Klenyem tertinggi diperoleh perlakuan P6 (70\% tepung ampas kelapa dan 30\% singkong parut) sebesar 30,54\% sedangkan kadar lemak terendah diperoleh pada perlakuan P1 (20\% tepung ampas kelapa dan 80\% singkong parut) yaitu sebesar $14,44 \%$.

Peningkatan kadar lemak terjadi seiring dengan penambahan tepung ampas kelapa. Hal ini disebabkan kadar lemak tepung ampas kelapa lebih tinggi dibandingkan dengan singkong. Kadar lemak tepung ampas kelapa berkisar 12,2\% (Yulvianti, et al. 2015) lebih tinggi nilainya daripada singkong yang memiliki kadar lemak berkisar 0,3\% (Septiriyani, 2017).

\section{Kadar Karbohidrat}

Hasil sidik ragam menunjukkan bahwa perbandingan rasio tepung ampas kelapa dengan singkong parut berpengaruh sangat nyata $(\mathrm{P}<0,01)$ terhadap kadar karbohidrat kue klenyem. Kadar karbohidrat kue klenyem berkisar 18,58\% sampai dengan 33,61\%. Kadar karbohidrat kue klenyem tertinggi diperoleh perlakuan P3 (40\% tepung ampas kelapa dan 60\% singkong parut) yaitu $33,61 \%$. Kadar karbohidrat kue klenyem terendah diperoleh pada perlakuan P5 (60\% tepung ampas kelapa dan $40 \%$ singkong parut) yaitu $18,58 \%$.

Perbedaan nilai kadar karbohidrat pada kue klenyem dari beberapa perlakuan menunjukkan nilai yang non signifikan. Hal ini disebabkan kadar karbohidrat sangat bergantung pada metode carbohydrate by different, yaitu angka 100 dikurangi kadar air, kadar abu, kadar protein dan kadar lemak (Sudarmadji, et al. 1997).

\section{Kadar Serat Kasar}

Hasil sidik ragam menunjukkan bahwa perbandingan rasio tepung ampas kelapa dengan singkong parut berpengaruh sangat nyata $(\mathrm{P}<0,01)$ terhadap kadar serat kasar kue klenyem. Kadar serat kasar kue klenyem berkisar 14,91\% sampai dengan 45,99\% (Tabel 2). Kadar serat kasar kue klenyem tertinggi diperoleh perlakuan P6 (70\% tepung ampas kelapa dan 30\% singkong parut) yaitu 45,99\%. Kadar serat kasar kue klenyem terendah diperoleh pada perlakuan P1 (20\% tepung ampas kelapa dan $80 \%$ singkong parut) yaitu $14,91 \%$. 
Semakin tinggi penambahan tepung ampas kelapa maka semakin tinggi pula kadar serat kasar yang terdapat pada kue klenyem. Diketahui tepung ampas kelapa memiliki kadar serat kasar lebih tinggi dibandingkan singkong parut. Hal ini dibuktikan dalam penelitian (Yulvianti, et al. 2015) menyatakan bahwa tepung ampas kelapa memiliki kadar serat kasar sebesar 20\%, sedangkan kadar serat kasar pada singkong parut hanya memiliki $0,73 \%$ (Feliana, et al., 2014).

\section{Sifat Sensoris}

Sensoris kue klenyem diuji dengan uji skoring dan uji hedonik (kesukaan). Nilai rata-rata uji skoring dan uji hedonik kue klenyem dapat dilihat pada Tabel 3.

Tabel 3. Nilai rata-rata uji skoring tekstur dan warna kue klenyem

\begin{tabular}{|c|c|c|c|c|c|}
\hline \multirow{2}{*}{$\begin{array}{c}\text { Perlakuan } \\
\text { (Tepung } \\
\text { Ampas } \\
\text { Kelapa : } \\
\text { Singkong } \\
\text { Parut) }\end{array}$} & Warna & Tekstur & Aroma & Rasa & \multirow{2}{*}{$\begin{array}{c}\text { Penerimaan } \\
\text { Keseluruhan } \\
\text { Hedonik }\end{array}$} \\
\hline & Skoring & Skoring & Hedonik & Hedonik & \\
\hline P1 (20:80) & $2,80 \mathrm{a}$ & $4,40 \mathrm{a}$ & $6,00 \mathrm{a}$ & $4,8 \mathrm{c}$ & $5,20 \mathrm{~cd}$ \\
\hline P2 (30:70) & $2,80 \mathrm{a}$ & $4,00 \mathrm{ab}$ & $5,87 \mathrm{a}$ & $4,8 \mathrm{c}$ & $5,40 \mathrm{bc}$ \\
\hline P3 (40:60) & $2,60 \mathrm{a}$ & $3,87 \mathrm{~b}$ & $6,07 \mathrm{a}$ & $6,4 \mathrm{a}$ & $6,40 \mathrm{a}$ \\
\hline P4 (50:50) & $2,53 \mathrm{a}$ & $3,80 \mathrm{~b}$ & $5,87 \mathrm{a}$ & $5,45 \mathrm{~b}$ & $6,00 \mathrm{ab}$ \\
\hline P5 (60:40) & $2,40 \mathrm{a}$ & $3,73 \mathrm{~b}$ & $5,67 \mathrm{a}$ & $5,33 \mathrm{bc}$ & $5,60 \mathrm{bc}$ \\
\hline P6 (70:30) & $2,33 \mathrm{a}$ & $3,67 \mathrm{~b}$ & $5,47 \mathrm{a}$ & $5,27 \mathrm{bc}$ & $4,67 \mathrm{~d}$ \\
\hline
\end{tabular}

Keterangan: Nilai rata - rata yang diikuti oleh huruf yang berbeda pada kolom sama menunjukkan perbedaan yang sangat nyata $(\mathrm{P}<0,01)$.

Skala Skoring Warna : 5 (coklat), 4 (kuning kecoklatan), 3 (kuning tua), 2 (kuning), 1 (kuning muda)

Skala Skoring Tekstur : 5 (keras), 4 (agak keras), 3 (agak lembut), 2 (lembut), 1 (sangat lembut)

Skala Hedonik : 7 (sangat suka), 6 (suka), 5 (agak suka), 4 (netral), 3 (agak tidak suka), 2 (tidak suka), 1 (sangat tidak suka).

\section{Warna Kue Klenyem}

Hasil sidik ragam menunjukkan perbandingan tepung ampas kelapa dan singkong parut tidak berpengaruh sangat nyata $(\mathrm{P}>0,01)$ terhadap warna kue klenyem. Tabel 3 menunjukkan bahwa nilai rata-rata warna kue klenyem berkisar 2,33 (kuning) sampai 2,80 (kuning). Data warna ini menunjukkan bahwa panelis menilai warna dari kue klenyem adalah kuning.

\section{Tekstur Kue Klenyem}

Hasil sidik ragam menunjukkan perbandingan tepung ampas kelapa dan singkong parut berpengaruh sangat nyata 
$(\mathrm{P}<0,01)$ terhadap tekstur kue klenyem.

Tabel 3 menunjukkan bahwa nilai rata-rata tekstur kue klenyem berkisar 3,67 (agak lembut) sampai 4,27 (keras). Data tekstur ini menunjukkan bahwa panelis menilai tekstur kue klenyem dari keras sampai agak lembut.

\section{Aroma Kue Klenyem}

Hasil sidik ragam menunjukkan perbandingan tepung ampas kelapa dan singkong parut tidak berpengaruh sangat nyata $(\mathrm{P}>0,01)$ terhadap aroma kue klenyem. Tabel 3 menunjukkan bahwa nilai rata-rata kesukaan panelis terhadap aroma kue klenyem berkisar 5,47 (agak suka) sampai 6,07 (suka).

\section{Rasa Kue Klenyem}

Hasil sidik ragam menunjukkan perbandingan tepung ampas kelapa dan singkong parut berpengaruh sangat nyata $(\mathrm{P}<0,01)$ terhadap rasa kue klenyem. Tabel 3 menunjukkan bahwa nilai rata-rata kesukaan panelis terhadap rasa kue klenyem berkisar 4,80 (netral) sampai 6,40 (suka). Kesukaan panelis tertinggi terhadap rasa pada perlakuan P3 (40\% tepung ampas kelapa dan $60 \%$ singkong parut) yaitu 6,40 (suka). Kesukaan panelis terendah terhadap tekstur diperoleh pada perlakuan P1 dan P2 yaitu 4,80 (netral).

\section{Penerimaan Keseluruhan Kue Klenyem}

Hasil menunjukan bahwa perbandingan tepung ampas kelapa dan singkong parut terhadap karakteristik kue klenyem berpengaruh sangat nyata $(\mathrm{P}<0,01)$ terhadap penerimaan keseluruhan kue klenyem. Secara keseluruhan dari segi rasa dan aroma kue klenyem yang paling disukai yaitu pada pada perlakuan P3 (40\% tepung ampas kelapa dan $60 \%$ singkong parut) yaitu 6,40 (suka). Rasio tepung ampas kelapa dan singkong parut yang mampu menghasilkan karakteristik terbaik pada kue klenyem yaitu pada perbandingan $40 \%$ tepung ampas kelapa dengan $60 \%$ singkong parut. Hal ini dibuktikan dari hasil sidik ragam yang signifikan terhadap kadar air, kadar abu, kadar lemak, kadar protein, kadar karbohidrat, kadar serat kasar, tekstur, rasa, dan penerimaan keseluruhan kue klenyem yang berpengaruh sangat nyata $(\mathrm{P}<0,01)$. Perbandingan presentase tersebut telah mampu memperbaiki tekstur dari kue klenyem menjadi lebih lembut daripada dipasaran. Serta penambahan $40 \%$ tepung ampas kelapa ini juga telah mampu meningkatkan kadar serat dari kue klenyem.

\section{KESIMPULAN DAN SARAN}

\section{Kesimpulan}

Penambahan tepung ampas kelapa berpengaruh terhadap kadar air, kadar abu, kadar lemak, kadar protein, kadar karbohidrat, serat kasar, tekstur, rasa dan penerimaan keseluruhan, tetapi tidak berpengaruh terhadap warna dan aroma dari kue klenyem. Kue klenyem dengan karakteristik terbaik diperoleh dari 
perbandingan $40 \%$ tepung ampas kelapa dan $60 \%$ singkong parut dengan kadar air $32,54 \%$, kadar abu 1,78\%, kadar protein $2,85 \%$, kadar lemak 33,72\%, kadar karbohidrat 33,61\%, kadar serat kasar $21,62 \%$, rasa suka $(6,40)$, aroma suka $(6,07)$, tekstur lembut $(3,80)$, warna kuning $(2,60)$ dan penerimaan keseluruhan suka $(6,40)$.

\section{Saran}

Berdasarkan hasil penelitian ini dapat disarankan untuk menggunakan formulasi perbandingan $40 \%$ tepung ampas kelapa dengan $60 \%$ singkong parut dalam pembuatan kue klenyem.

\section{DAFTAR PUSTAKA}

Anonim. (2011). Jemblem Klenyem Misro Jotosan Krandon Entho Cothot. https://enkoos.com/2011/05/25/jemblem -Klenyem-misro-jotosan-krandon-enthocothot/. [diakses pada tanggal 4 Maret 2019].

Anonimus. (2015b). Cara Membuat Kue Klenyem.

http://gudangilmu2712.blogspot.com/20 15/03/cara-membuat-kue-Klenyem.html. [diakses pada tanggal 3 Maret 2019].

Feliana, Firga., A.H, Laenggeng., dan F. Dhafir. (2014). Kandungan Gizi Dua Jenis Varietas Singkong (Manihot esculenta) Berdasarkan Umur Panen Di Desa Siney, Kecamatan Tinombo Selatan, Kabupaten Parigi Moutong.
Jurnal E-Jipbiol. Vol. 2, No. 3, Hal : 4

Putri, M. F. (2014). Riset dan Inovasi Pendidikan Vokasional pada Karakteristik Sensoris Cookies dengan Substitusi Tepung Ampas Kelapa. Jurusan Teknologi Jasa dan Produksi Prodi Tata Boga Fakultas Teknik. Universitas Negeri Semarang, Semarang. Rosnah dan Wa Zulhija. (2018). Penambahan Tepung Ampas Kelapa Mempengaruhi Karakteristik Sensorik dan Kadar Serat Kasar Nugget Ikan Cakalang (Thunnus Macoyii). Jurnal Penelitian Kesehatan Suara Forikes. Vol. 9, No. 4, Hal : 238.

Septiriyani, VI. (2017). Potensi Pemanfaatan Singkong (Manihot utilissima L) Sebagai Bahan Tambahan Dalam Pembuatan Es Puter Secara Tradisional. Program Studi Pendidikan Biologi. Jurusan Pendidikan Matematika dan Ilmu Pengetahuan Alam. Fakutas Keguruan dan Ilmu Pendidikan, Universitas Sanata Dharma. Yogyakarta. Sudarmadji, S., B. Haryono., dan Suhardi. (1997). Analisis Bahan Makanan dan Pertanian. Liberty. Yogyakarta

Soekarto, S.T. (1985). Penilaian Organoleptik Untuk Industri Pangan dan Pertanian. Bharata Karya Aksara. Jakarta

Wardani, E.N. (2016). Karakteristik Cookies Ubi Jalar Ungu Dengan Penambahan Tepung Ampas Kelapa. Program Studi Ilmu dan Teknologi Pangan. Fakultas Teknologi Pertanian. Universitas Udayana, Bali.

Yulvianti, M., E. Widya, Tarsono, dan A. R. Muhammad. (2015). Pemanfaatan Ampas Kelapa Sebagai Bahan Baku Tepung Kelapa Tinggi Serat Dengan Metode Freeze Drying. Jurnal Integrasi proses, Vol. 5, No. 2, Hal : 101-107. 